\title{
Shades of Green — or Grey? Towards an Ecological Interpretation of Jonah 4:6-11 ${ }^{1}$
}

\author{
SCHALK WILLEM VAN HEERDEN (UNISA)
}

\begin{abstract}
Most scholars who have attempted ecological interpretations of the Jonah narrative regard Jonah 4:6-11, especially the reference to the animals of Nineveh in 4:11, as an obvious starting point for a retrieval of ecological wisdom in the narrative. A notable exception is the Green Bible team, who selected, and printed in green, more than a thousand biblical passages which, in their view, support the aims and principles of creation care, including five passages from the Jonah narrative. However, not a single verse in Jonah ch. 4 is printed in green. A number of scholars indeed argue that no ecological wisdom can be retrieved from the passage under discussion, particularly 4:11, because the reference to animals is made in the context of forthcoming sacrifices from the newly pardoned, grateful Ninevites. Ehud Ben Zvi contends that a double reading of 4:11 is possible. This study argues that the work of Ben Zvi provides an angle from which more nuanced ecological readings of the Jonah narrative can be done.
\end{abstract}

KEYWORDS: ecological hermeneutics; book of Jonah; Jonah 4:6-11; animals; animal sacrifice.

\section{A INTRODUCTION}

“And many animals." Several scholars regard this phrase - the words that conclude the Jonah narrative — as an obvious starting point for an ecological reading of the narrative. For Ernst Conradie ${ }^{2}$ this passage is the obvious starting point for retrieving ecological wisdom in the book of Jonah because it expresses God's remarkable mercy that extends not only to humans, but also to their

* Article submitted: 24/04/2017; peer-reviewed: 26/05/2017; accepted: 7/06/2017. Schalk Willem van Heerden, "Shades of Green — or Grey? Towards an Ecological Interpretation of Jonah 4:6-11,” OTE 30/2 (2017): 459-477, doi: 10.17159/23123621/2017/v30n2a16

1 I dedicate this article to Izak Spangenberg in celebration of 30 years of collegiality and friendship. Early during his academic career his views on Jonah drew considerable attention; more recently he has developed a keen interest in ecological theology.

2 Ernst Conradie, “An Ecological Hermeneutics," in Fishing for Jonah (Anew): Various Approaches to Biblical Interpretation, ed. Louis Jonker and Douglas Lawrie (Stellenbosch: SUN Press, 2005), 226. 
domesticated animals. Yael Shemesh ${ }^{3}$ and Kathryn Schifferdecker ${ }^{4}$ use the phrase, "And many beasts" / "And also many animals" as the main title of their studies on respectively the function and status of animals in the book of Jonah, and biblical resources for preaching about creation.

Therefore, I was surprised to see that in The Green Bible $e^{5}$ this verse is not printed in green. In this green-letter edition of the New Revised Standard Version more than a thousand passages in the Bible selected on the basis that they support the aims and principles of creation care are printed in green. ${ }^{6}$ Why have the final verses of Jonah been excluded - a passage which eco-theologians regard as an obvious starting point for retrieving ecological wisdom from the Jonah narrative?

I then discovered that a number of Jonah studies understand the final verses of the book in ways that do not resonate well with the notion of creation care. Several exegetes argue that the first (re)readers of the narrative would understand the reference to animals in 4:11 in terms of a framework which emphasises God's sovereignty, rather than God's mercy. These scholars say the text may not be about the boundlessness of divine love, which is also aimed at non-human members of the earth community, but rather the limitless of God's power. ${ }^{7}$

This article is an attempt to explore possible readings of the final verses of the book of Jonah and the implications of these readings for ecological interpretations of this text. The first part offers a brief overview of extant interpretations of this passage. Part two consists of ecological readings of the text. The final section focuses on the implications of this exploration for ecological interpretations of the book of Jonah and biblical texts in general.

3 Yael Shemesh, “'And Many Beasts’ (Jonah 4:11): The Function and Status of Animals in the Book of Jonah,” JHebS 10 (2010), Article \#6, 26 pages; online: http://www.jhsonline.org/Articles/article_134.pdf.

4 Kathryn Schifferdecker, “'And Also Many Animals’: Biblical Resources for Preaching about Creation,” WW 27 (2007): 210.

5 The Green Bible: A Priceless Message that Doesn't Cost the Earth, NRSV ed. (London: Collins, 2008), 906.

6 The Green Bible, 1-15.

7 See for example Thomas M. Bolin, "Jonah 4.11 and the Problem of Exegetical Anachronism,” SJOT 24 (2010): 102, doi: 10.1080/09018328.2010.491605. See also Alan M. Cooper, "In Praise of Divine Caprice: The Significance of the Book of Jonah,” in Among the Prophets, ed. Philip R. Davies and David J. A. Clines (Sheffield: Sheffield Academic Press); Philippe Guillaume, "The End of Jonah is the Beginning of Wisdom," Bib 87 (2006); Ehud Ben Zvi, "Jonah 4:11 and the Metaprophetic Character of the Book of Jonah,” JHebS 9 (2009), Article \#5, 13 pages, online: http://www.jhsonline.org/Article/ article 107.pdf. 


\section{B INTERPRETATIONS OF THE FINAL VERSES OF THE JONAH NARRATIVE: AN OVERVIEW}

In Jonah 4:11 the connection between the people of Nineveh and their (domesticated) animals has been interpreted in several ways. Some readings are linked to an understanding of the narrative which sees its message as an affirmation of God's boundless mercy and care for creation. Other readings, however, claim that the narrative does not focus on God's wide mercy, but on God's sovereignty — the limitlessness of God's power.

Those who read the narrative as an affirmation of divine mercy understand the relationship between the Ninevites and their animals in at least three ways. ${ }^{8}$ According to one reading, the Ninevites are seen to be as dumb as their animals. This reading is supported by the fact that God refers to the Ninevites in 4:11 as people who do not know their right from their left. Such ignorance is thus more deserving of forbearance than punishment. An interesting version of this view is found in Verduin's reading of the text. ${ }^{9}$ He contrasts Jonah's self-righteous attitude to that of the Ninevites who know that they live like animals (in Dutch: "de beest uithangen"), but come to realise that they are in need of a shepherd. They, not Jonah, would understand the words of Ps 73:22 "I was stupid and ignorant; I was like a brute beast toward you."

Another reading ascribes human qualities to the animals so that their innocence vis-à-vis God's wrath is emphasised. Innocence calls for divine mercy. According to this view, the remark about the Ninevites' inability to distinguish between right and left is interpreted as an almost childlike naivete. This reading finds support in the statement that the animals are also subject to the fasting, clothing in sackcloth, and so forth decreed by the king of Nineveh. James Limburg, for example, concludes with reference to the many people who do not know their right from their left that the Ninevites are portrayed as helpless, and therefore can show solidarity with the animals "grazing on an Assyrian hillside." ${ }^{10}$ He points out that the reader is reminded of what Jesus said about God's care for even the sparrows (Matt 10:29-31). ${ }^{11}$

According to a third reading, the 120000 in Nineveh who do not know their right from their left refer to young children. This in effect combines the above two readings: the mental capacities of infants can be compared to that of dumb animals, and as infants, so is the innocence of the animals. ${ }^{12}$ Deist ${ }^{13}$ points

8 For example Bolin, “Jonah 4.11,” 101-102.

$9 \quad$ M. Verduin, De Spiegel van het Boek Jona (Kampen: J. H. Kok, 1984), 91.

10 James Limburg, Jonah (London: SCM, 1993), 97-98.

11 Limburg, Jonah, 98.

12 Cf. Bolin, “Jonah 4.11,” 101, and Ferdinand E. Deist, Die God van Jona (Cape Town: Tafelberg, 1981), 58.

13 Deist, God van Jona, 58. 
out that Jonah wishes to die, although ironically the mercy about which he is so upset spares the lives of 120000 children (people who do not know right from left) and many livestock. To Jonah justice instead of mercy should triumph. He is prepared to die instead of showing compassion.

In addition the above three readings discussed by Bolin, ${ }^{14}$ others see the animals in Jonah 3 and 4 as a comic element in the book, suggesting that the conversion of the Ninevites was ridiculous and superficial. ${ }^{15}$ John A. Miles reads Jonah as a parody, and is convinced that the portrayal of the animals surely prompted a smile:

The last line in particular, with its closing words ובהמה רבה "plus the many animals," must surely prompt a smile; for if Jonah is foolish in his resentment, the Ninevites, dressing their animals in sackcloth and forcing them to fast, have been foolish in their repentance. God concedes this much to Jonah. ${ }^{16}$

Yet others claim that 4:11 does not speak about animals at all. Shemesh ${ }^{17}$ gives two examples of this reading: a) Rashi says the phrase "and many animals" actually refers to adult people with the intelligence of beasts (alongside children who do not yet know the difference between their right and their left). b) Deuteronomy Rabbah argues that the phrase alludes to the evildoers among the citizens of Nineveh, whereas the 120000 persons are the righteous in the city.

The above readings, which for centuries have been a common reading of the narrative, all assume that the Jonah narrative affirms God's boundarycrossing compassion and mercy (though in some cases restricted to humans).

However, recently some scholars have offered very different understandings of the Jonah narrative and the final verse of the book in particular. ${ }^{18}$ Thomas

14 Bolin, “Jonah 4.11,” 101-102.

15 Cf. Steven L. McKenzie, “The Genre of Jonah,” in Seeing Signals, Reading Signs: The Art of Exegesis: Studies in Honour of Anthony F. Campbell, SJ for his Seventieth Birthday, ed. Howard N. Wallace and Mark A. O’Brien, JSOTSup 415 (Sheffield: Sheffield Academic Press, 2005), 159-171.

16 John A. Miles, "Laughing at the Bible: Jonah as Parody,” JQR 65 (1974-1975): 180. 17 Shemesh, "Function and Status of Animals," 3.

18 For example, Thomas M. Bolin, “'Should I Not Also Pity Nineveh?' Divine Freedom in the Book of Jonah,” JSOT 67 (1995); Thomas M. Bolin, Freedom Beyond Forgiveness: The Book of Jonah Re-examined, JSOTSup 236 (Sheffield: Sheffield Academic Press, 1997); Thomas M. Bolin, "Eternal Delight and Deliciousness: The Book of Jonah after Ten Years," JHebS 9 (2009), Article \#4, 11 pages, online: http://www.jhsonline.org/Articles/article_106.pdf; Bolin, "Jonah 4.11”; Yvonne Sherwood, A Biblical Text and its Afterlives: The Survival of Jonah in Western Culture" (Cambridge: Cambridge University Press, 2000); Ehud Ben Zvi, Signs of Jonah: Reading and Rereading in Ancient Yehud, JSOTSup 367 (Sheffield: Sheffield 
M. Bolin ${ }^{19}$ points out that most commentators connect the בהמה of 4:11 to those included in the king's decree ordering repentance and supplication in 3:7-8. However, he says, what is often overlooked, apart from the fact that God notices the animals in Nineveh, is why God would be interested in them at all. His explanation is that

YHWH, like all his divine colleagues in the ancient Mediterranean and Near Eastern worlds, feasted on a daily diet of roasted animal flesh and that his reference to the animals is made in the context of forthcoming sacrifices from the newly pardoned (and grateful) Ninevites. $^{20}$

Bolin finds support for this explanation in the role of sacrifice in Jonah. Twice the practice is mentioned explicitly: first in 1:16 where the sailors made sacrifices to YHWH along with vows after the sea ceased from its raging and also in 2:10 where Jonah promises to sacrifice to YHWH, also connected with a vow, if YHWH would rescue him from his ordeal in the belly of the fish. In both instances the verb זבח is used, which in the HB always refers to animal sacrifice. Bolin ${ }^{21}$ understands both of the references to sacrifice in Jonah as an expression of gratitude to the deity in response to an act of divine beneficence.

Consequently, Bolin argues, "one may validly enquire whether or not YHWH's mention of the animals in 4:11 is motivated by his anticipation of thankofferings on the part of the Ninevites in response to his pardon of their sinfulness." 22 In view of the parallel portrayals of the sailors and the Ninevites, one might expect a reference to thank-offerings of the Ninevites. ${ }^{23}$

Bolin ${ }^{24}$ claims that this way of looking at the reference to Nineveh's animals in 4:11 suggests a new reading of the book as a whole, namely as a narrative that describes the inexorable will of YHWH to extend his sphere of influence over the whole world. From this perspective, YHWH's command that Jonah go to Nineveh is not motivated by mercy or compassion or a non-sectarian concern for all the peoples of the earth. Rather, this command is the action of a ruler. Bolin asks:

[W]hat are gods in antiquity but kings writ large? — doing what all rulers in the ancient Near East did: trying to extend his sphere of

Academic Press, 2003); Ehud Ben Zvi, “Jonah 4:11”; Lowell K. Handy, Jonah’s World: Social Science and the Reading of Prophetic Story, (New York: Routledge, 2007).

19 Cf. Bolin, "Eternal Delight and Deliciousness," 9.

20 Cf. Bolin, "Eternal Delight and Deliciousness," 9.

21 Cf. Bolin, "Eternal Delight and Deliciousness," 9.

22 Bolin, "Eternal Delight and Deliciousness," 10.

23 Cf. Bolin, "Eternal Delight and Deliciousness,” 10.

24 Cf. Bolin, "Eternal Delight and Deliciousness,” 10. 
influence. This was the practice of the Persian monarchs under whose rule the author of Jonah most likely lived. ${ }^{25}$

Philippe Guillaume also suggests that the Jonah narrative is not about God's mercy and compassion, but about the acknowledgment of the experience of the Jonah character. Guillaume, ${ }^{26}$ following the earlier work of Alan Cooper, ${ }^{27}$ questions the widely-held view that the book of Jonah ends with a rhetorical question. Guillaume reads the final verse as an affirmation instead of an interrogative. Hence, the translation he offers of the final verses of the book: "You grieved over the qiqayon ... but as for me, I will not grieve over Nineveh." ${ }^{28}$ He points out that, from a grammatical point of view, the text can be read both ways, and that the choice impacts the understanding of the whole book. Guillaume $^{29}$ finds support for his preference for an affirmative reading of the verse in several parts of the narrative: (a) The way the other two questions directed at Jonah have been indicated $(4: 2 ; 4: 4,9)$ support an affirmative reading. (b) Reading 4:11 as a rhetorical question leaves many problems unresolved. (c) The truthfulness of the divine word in case the punishment of the Ninevites will indeed be meted out, which according to Guillaume would mean that the Jonah story "ponders over the rise and fall of cities." 30 (d) Jonah's anger, which was not about the elements of nature that hurt him, but about "the defense of justice from the encroachment of mercy." 31 Reading the text as a rhetorical question evades the issue of cheap mercy. However, with a final assertive reading, "YHWH raises to the challenge, acknowledging Jonah's point while introducing the issue of delay. Delayed punishment is not pardon."32 (e) Reference to the Jonah-figure in 2 Kgs 14:25, since both texts share a lack of coherence between human behaviour and divine response. 2 Kgs 15:23-29 portrays Jeroboam as a sinful king who, during his long reign, was able to restore the borders of his kingdom according to the words of the prophet Jonah, because YHWH had seen the suffering of his people. However, the readers of Jonah were well aware that both the northern kingdom and Nineveh were eventually destroyed. The interplay between the text and the shared history of the readers would mean that in the long run justice prevails, although in the Jonah narrative mercy was shown to the Ninevites despite their evil ways, because God saw their fasting and heard their cries. According to Guillaume's reading of Jonah,

\footnotetext{
25 Bolin, "Eternal Delight and Deliciousness,” 10.

26 Cf. Guillaume, “End of Jonah,” 243.

27 Cf. Cooper, "In Praise of Divine Caprice.”

28 Guillaume, "End of Jonah,” 243.

29 Cf. Guillaume, “End of Jonah,” 245-250.

30 Guillaume, "End of Jonah,” 247.

31 Guillaume, "End of Jonah," 247.

32 Guillaume, “End of Jonah,” 248.
} 
[d]ivine sovereignty is beyond human understanding. God's decrees cannot be manipulated ... God confirms the validity of the judgment that Jonah was sent to proclaim. Rather than being rebuffed, Jonah is put on a par with Job. Both suspected God to be unfair, in Jonah's case that God was too lenient and in Job's that he was too hard. Both despised their own lives, not because of suicidal tendencies, but out of a deep consciousness of divine justice. God vindicated both in the end. ${ }^{33}$

Ehud Ben Zvi ${ }^{34}$ agrees that both interrogative (in this case rhetorical) and asseverative readings of Jonah 4:11 are possible. He offers valuable insights into the use of rhetorical questions:

[U]nlike ordinary information seeking questions, rhetorical questions have the illocutionary force of an assertion; in fact of a very strong assertion and are likely to carry an affective appeal. Rhetorical questions tend to relate to what precedes them in a communicative interaction and often tend to convey a challenge to the "recipient" of the communication, to a previous statement made in the conversation, or both, on the basis of a presumed shared knowledge. ${ }^{35}$

Ben Zvi points out that rhetorical questions have been associated with teaching techniques aimed at self-correction on the basis of the recipient's existing knowledge. ${ }^{36}$ In sophisticated literary texts, rhetorical questions may play on multiple layers of meaning and lack of certainty. ${ }^{37}$

According to Ben Zvi there is no doubt that later readers of Jonah 4:11 did understand 4:11 as a rhetorical question. ${ }^{38}$ As a historian, Ben Zvi is interested in the issue whether the same holds for the intended and primary rereaders of the book of Jonah, likely in the late Persian period. To answer this question, he says, one must deal with three related issues: (a) whether the literary elite among whom and for whom the book was written were aware of the device of rhetorical questions; (b) whether they could understand Jonah 4:11 as a question; and if the answers to (a) and (b) are "yes," (c) whether there are clues in the text that may have led the literary elite to understand Jonah $4: 11$ as a rhetorical question. ${ }^{39}$

Ben Zvi says the first question is easily answered. These literary elite were well versed in the use of rhetorical questions, and rhetorical questions are well

33 Guillaume, “End of Jonah,” 250.

34 Ben Zvi, “Jonah 4:11,” 2.

35 Ben Zvi, “Jonah 4:11,” 3.

36 Cf. Ben Zvi, “Jonah 4:11,” 3.

37 Cf. Ben Zvi, “Jonah 4:11,” 4.

38 Cf. Ben Zvi, "Jonah 4:11,” 5.

39 Cf. Ben Zvi, “Jonah 4:11,” 5. 
attested, not only in the HB, but also in in ANE cultures in general. "The literary elite depended on their world of knowledge, not only grammatical or syntactic considerations, to decide when a question is rhetorical or not." 40

With regard to the second issue, Ben Zvi affirms that the literati indeed could read Jonah 4:11 as a rhetorical question. They were well aware that questions in general did not have to be marked by interrogative pronouns or particles. In oral speech, rhetorical questions were marked by intonation, but in written texts this situation leads to less fixed readings, possible ambiguities and multivalence. Ben Zvi points out that the literary elite in Yehud, including those who were responsible for the prophetic books, relished such literary devices. ${ }^{41}$

With regard to the third question, Ben Zvi also gives a positive answer to the question whether the textual context could suggest to the literary elite that Jonah 4:11 might be read as a question. ${ }^{42}$ Textual markers indeed invited the first readers of the text to consider reading this verse as a rhetorical question. Readings informed by ch. 3 and by a theological outlook in which repentance plays an important role would have raised the possibility of a reading of the book in which the city is not destroyed. Furthermore, the divine speech in 4:11 is clearly marked to highlight three sets of pairs: (a) the subjects: "you" (Jonah) in contrast to "I" (YHWH); (b) verbal forms: the "positive qtl form of חוס in the qal" in contrast to the "negative yqtl form of חוס in the qal"; 43 and (c) two על clauses: on the one hand the phrase about the קיקיון, for which Jonah did not labour and which he did not grow; it came into being in a night and perished in a night; and on the other hand the phrase about Nineveh, that great city, in which there are more than a hundred and twenty thousand persons who do not know their right hand from their left, and also many animals. ${ }^{44}$

An interesting element of the contrasting אשר clauses in 4:10-11, is the contrast between a plant on the one hand, and people and animals on the other. The text seems to evoke a widely accepted hierarchy of being in which people and then animals stand well above plants. "To destroy a plant was not considered the same as to kill animals and certainly human beings." 45 The deity employs here a clear case of qal wahomer and a resulting rhetorical question. According to Ben Zvi the goal of both would be to encourage self-correction in Jonah. ${ }^{46}$

40 Ben Zvi, “Jonah 4:11,” 6.

41 Cf. Ben Zvi, “Jonah 4:11,” 7.

42 Cf. Ben Zvi, “Jonah 4:11,” 8.

43 Cf. Ben Zvi, “Jonah 4:11,” 8.

44 Cf. Ben Zvi, “Jonah 4:11,” 8.

45 Cf. Ben Zvi, “Jonah 4:11,” 9.

46 Cf. Ben Zvi, “Jonah 4:11,” 9. 
Ben Zvi summarises his findings as follows ${ }^{47}$ :

[R]eadings of 4:11 as an interrogative created no grammatical problems, are coherent with the expectations evoked by the lack of destruction of Nineveh envisaged in chapter 3, Jonah's response at the beginning of chapter 4, and the literati's knowledge that Nineveh was not destroyed during the time of Jeroboam II. Such views were also consistent with the literati's worldview in terms of the importance of repentance and ritual, which is also stressed in Jonah 1-3, as well as with some of the attributes they used to describe YHWH (e. g. merciful).

But were interrogative readings of Jonah 4:10-11 the only readings possible among the literary elite in Yehud? Surely not, says Ben Zvi, who gives four reasons for his answer: ${ }^{48}$ First, grammatically, the text was constructed in such a way that it could be read as an assertion. Secondly, the literary elite certainly knew about the destruction of both Nineveh and Jerusalem. Thirdly, a declarative reading would resonate with some of the theological positions that existed in the discourse of the literary elite, for example about the eventual fulfilment of YHWH's word, including its potential postponement. Finally, a declarative reading also finds support in some markers found in the text. Such a reading would, for example, contrast Jonah, a human who felt "pity" to a plant, to a deity who does not show "pity." Unlike Jonah or human beings, the deity does not benefit from, but just uses as temporary tools plants, animals, and human beings, including Jonah, the sailors and people of Nineveh.

Ben Zvi concludes that an implied author did not pick one reading reading the final verse either as a rhetorical question or as an assertion - and rejected the other. ${ }^{49}$ He argues that the open ended conclusion of the book and the lack of an explicit interrogative particle are consistent with an image of an implied author that encourages the re-readers to consider both understandings of the verse, which would imply that the two readings inform and balance each other. ${ }^{50}$ The play on the word נהפכת (to be overturned/destroyed or to be turned around) in Jonah 3:4 hints at such a double reading of the narrative.

Ben Zvi finds support in the work of Edelman who stresses that the following pitfalls should be avoided when reading prophetic books: (a) a failure to grapple with the multivalent nature of many prophetic utterances, (b) a failure to integrate conflicting views into a larger picture that allows both to be included, and (c) a decision to read prophetic texts only as predictions for God's future

47 Ben Zvi, “Jonah 4:11,” 10.

48 Cf. Ben Zvi, “Jonah 4:11,” 10-11.

49 Cf. Ben Zvi, “Jonah 4:11,” 11.

50 Cf. Ben Zvi, “Jonah 4:11,” 12. 
action in history, insisting on their fulfilment in reality and not acknowledging their function as illustrations of the divine nature and will. ${ }^{51}$

Within the context of the literary elite of Yehud, two readings of the book of Jonah inform each other. The plot of the narrative as a whole raises the basic expectation of the non-destruction of Nineveh. This expectation reflects the construction of a partial image of YHWH as a compassionate, merciful God that would not destroy a repentant city (see also Jer 18:7-10), and that humans are not much different from animals in discerning between good and evil (see also Joel 2:13; Jonah 4:2; Ps 86:15; 103:8; Neh 9:31). However, the literary elite in the Persian period also knew that YHWH is willing to and has indeed destroyed both Nineveh and Jerusalem. Within their discourse, they could not but evoke complementary and balancing images of YHWH. ${ }^{52}$

The findings of Ben Zvi are complemented by the work of Lowell K. Handy in a book titled “Jonah's World: Social Science and the Reading of Prophetic Story." 53 Handy aims to reconstruct the social world into which the Jonah narrative was released and which it reflects. He also dates the book in the Persian period, an essentially peaceful time when Judah had a definable identity. It was a time when the events of both Assyria's demise and Babylonian incorporation into the Persian empire were well in the past and yet still of interest to the intellectual circles. Handy points out that the literary elite of Yehud at that time would have been serving two masters: the Jerusalem temple cult and the Persian administration. The Jonah narrative therefore "reflects both a Judean theology and an imperial polity." 54

The two possible readings of Jonah 4:10-11 proposed by Ben Zvi can be understood in terms of the two "masters" (or perhaps better: "required loyalties") served by the trained scribes of Persian Yehud, namely the Yahwist faith and the Persian administration. An assertive reading of 4:11 emphasises the unlimited power of YHWH (reflecting royal sovereignty and power), while an interrogative reading highlights the boundlessness of the deity's mercy, as experienced in the Jerusalem cult.

From a literary point of view, the Jonah narrative is replete with wordplay on a number of levels. Baruch Halpern and Richard Elliott Friedman distinguish between three levels of word-play: the repetition of key words, allusion to

51 Cf. Ben Zvi, “Jonah 4:11,” 11; see also Diana V. Edelman, “Jonah Among the Twelve in the MT: The Triumph of Torah over Prophecy,” in The Production of Prophecy: Constructing Prophecy and Prophets in Yehud, ed. Diana V. Edelman and Ehud Ben Zvi (London: Equinox, 2009), 155.

52 Cf. Ben Zvi, “Jonah 4:11,” 12.

53 Handy, Jonah's World.

54 Handy, Jonah's World, 15. 
a similar word, and the semantic ambiguity of a particular word. ${ }^{55}$ The latter two levels of word-play are of particular interest to me, since the dynamics of wordplay parallels the notion of a double reading of 4:11, as explained by Ben Zvi. I will restrict myself to two examples, both taken from Jonah 4:10-11.

The first is the word בהמה. The word usually refers to domestic animals, but, as Shemesh points out, it may also be a collective term for all four-footed creatures, for example in 1 Kgs 5:13 [4:33] (animals); 1 Sam 17:44 and Joel 1:20 (wild animals of the field); Mic 5:7 [8] (animals of the forest); Deut 32:24 (beasts). ${ }^{56}$ If one would read 4:11 as an assertion about the execution of power and control, the image of domesticated animals is invoked. Alternatively, those who read the verse as a rhetorical question, tend to emphasise the allencompassing mercy and compassion of the deity, and sometimes understand the word in the sense of animals/beasts in general. Shemesh for example says: “The very last words — 'and many beasts' — indicate that divine mercy transcends human beings and includes animals as well.”57

The use of the word חוס offers another example of possible word-play. Sasson, for example, proposes two different meanings for the word, namely "fret" for Jonah, and "have compassion" for YHWH. ${ }^{58}$ He argues that in Jonah 4:10-11 the Hebrew attains two distinct meanings by using the same verb, hus. If one would emulate the Hebrew by using the same verb in another language in both vv. 10 and 11, one might have compromised the meaning for one of the

55 Baruch Halpern and Richard E. Friedman, "Composition and Paranomasia in the Book of Jonah,” HAR 4 (1980): 80, 83, 86.

56 Cf. Shemesh, "Function and Status of Animals," 3.

57 Shemesh, "Function and Status of Animals," 3.

58 Cf. Jack M. Sasson, Jonah: A New Translation with Introduction, Commentary, and Interpretation, AB (New York: Doubleday, 1990), 300. However, some Bible translations render חוס "to have concern" (NIV, NRSV), which is a general term that masks the possible exploitation of word-play. Others argue that the application of the חוס Tord to Jonah's actions and attitude is an example of irony. The author means the opposite of how the word is normally understood, see for example Hans W. Wolff Obadiah and Jonah: A Commentary (Minneapolis: Fortress, 1986), 173-174. Phyllis Trible, "Jonah," NIB 7: 523-524 opts for a reading of wich is based on the technique of delayed information. Her proposal returns to the three incidents of 4:6-8: In the first incident (4:6) Jonah was very happy about the plant in a self-serving way. The plant provided him with shade. In the third incident (4:8) Jonah became very angry, fainted and asked that he might die. This response was also self-serving. But between these two incidents a worm attacked the plant and it withered (4:7). The narrative does not tell how Jonah responded to the withering of the plant qua plant. Trible, "Jonah," 524 suggests that at the close of the story this gap is filled where Adonai says "You, you pitied the plant," which in her opinion refers to an action which is not self-serving. 
contexts. ${ }^{59}$ Sasson uses the translation of Butterworth to illustrate the point. ${ }^{60}$ Butterworth renders the phrase in 4:10 "you are sorry to lose the plant," and in 4:11 “should I not be sorry to lose Nineveh?” If one would accept Butterworth's translation of 4:10 (referring to Jonah), but opt for Sasson's translation of 4:11 (referring to YHWH), the two verses could be rendered: "You, yourself, were sorry to lose the קיקיון plant... yet I myself am not to have compassion on Nineveh...?” Hence, the ambiguity inherent to might also be in the service of the two "masters" referred to by Handy. ${ }^{61}$

\section{READINGS OF JONAH 4:11 BY SCHOLARS WHO ATTEMPTED ECOLOGICAL INTERPRETATIONS OF THE NARRATIVE}

Let us now turn to a sample of ecological readings of Jonah 4:10-11. The first to use this lens for reading the book of Jonah was Phyllis Trible. ${ }^{62}$ She is aware of both God's control over the world of nature which belongs to the deity, and an ecology of pity. With regard to God's control over nature, she says:

The world of nature belongs to God, who uses it at will, A plant represents flora; a worm, fauna. The natural times of day, symbolized by the dawn and the rising of the sun, cooperate with the divine plan. ${ }^{63}$

So far Trible's description between the relationship between nature and the deity sounds like the relationship between a sovereign king and obedient subjects, which resonates well with a declarative reading of 4:11. However, she also argues that

[a]t the end of the story the divine use of nature yields to respect for the integrity of creation. Jonah pities the withered plant in and of itself, apart from the effect of its withering upon him. He becomes thereby the model for YHWH, free of self-interest. An ecology of pity becomes the paradigm for a theology of pity, and that pity embraces not just the human population of Nineveh but also its animals. ${ }^{64}$

Trible does not keep the two possible readings of 4:10-11 in a creative tension. She suggests that the unfolding of the story paves the way for the triumph of the interrogative reading of the final verse.

\footnotetext{
59 Cf. Sasson, Jonah, 309-310.

60 Cf. Sasson, Jonah, 310.

61 Handy, Jonah's World, 15.

62 Phyllis Trible, "Jonah,” (see footnote 58 above) and Phyllis Trible, “A Tempest in a Text: Ecological Soundings in the Book of Jonah," in On the Way to Nineveh: Studies in Honor of George M. Landes, ed. Stephen L. Cook and Sara C. Winter (Atlanta: Scholars Press, 1990).

63 Trible, “Jonah,” 525.

64 Trible, “Jonah,” 525.
} 
Two scholars employed an ecological hermeneutical framework, which was developed by members of The Earth Bible Project, to interpret the Jonah narrative. In 2005 Ernst M. Conradie, ${ }^{65}$ and in 2008 Raymond F. Person Jr. ${ }^{66}$ read the book through this lens. This eco-hermeneutical framework involves a hermeneutic of suspicion and retrieval (later the element of identification was also included in this model). One of the primary aims of this model is to unmask the anthropocentric bias that we are likely to find both in ourselves as readers and in the texts we are reading. ${ }^{67}$ This approach is also known as an eco-justice approach.

Both Conradie and Person read 4:11 as a rhetorical question which emphasises the inclusiveness of God's mercy. Conradie says:

This question expresses God's remarkable mercy that extends not only to human beings but also to their domestic animals. The animals and natural forces are indeed intimately involved and incorporated in the drama of creation, providence (the role of the fish in 1:17, 2:10), human evil (1:2), divine judgment (the storm, the wind, the desert wind, also the role of the worm in 4:7), repentance (the animals that were expected in 3:7 to fast too) and the expected final restoration (4:11). God's shalom is aimed at establishing a comprehensive sense of well-being that includes the whole community of creation. ${ }^{68}$

True to an eco-hermeneutical framework which has an element of suspicion, Conradie asks whether this inclusiveness is sustained in the narrative as a whole. He wonders whether the use of natural motifs such as the fish, the plant, and the worm is predominantly instrumentalist. These elements of nature are not really fully-fledged role players that are respected for their own integrity. These motifs are merely used to make the story more picturesque, amusing and pedagogically effective. He also points out that only domesticated animals are mentioned. Furthermore, the only plant in the story is scorched in the process of God's effort to teach Jonah a lesson. Furthermore, the sea is portrayed as a dangerous threat, with little acknowledgement that the sea provided the habitat from which our forms of life originated. Conradie admits that these observations are perhaps overly critical, and that the dominant thrust of the book is one of inclusiveness:

65 Conradie, "Ecological Hermeneutics.”

66 Raymond F. Person, “The Role of Nonhuman Characters in Jonah,” in Exploring Ecological Hermeneutics, SBLSS 46, ed. Norman C. Habel and Peter Trudinger (Atlanta: Society of Biblical Literature, 2008).

67 Norman C. Habel, "Introducing Ecological Hermeneutics," in Exploring Ecological Hermeneutics, ed. Norman C. Habel and Peter Trudinger (Atlanta: Society of Biblical Hermeneutics, 2008), 4.

68 Conradie, "Ecological Hermeneutics,” 226. 
It counters an exclusivist preoccupation with the interests of one nation, one culture, one person, one species. The vision is one of God's astonishing mercy that extends over the whole of creation. ${ }^{69}$

Raymond Person focuses on the role of non-human characters in Jonah, most of which appear in ch. 4 - the animals of Nineveh (4:11), as well as the קיקיון plant (4:6-10), the worm (4:7), the east wind (4:8) and the sun (4:8). Person describes the non-human characters as "active, independent agents who obediently respond to the Lord."70 He stresses that although YHWH, the Creator of the sea and the dry land, is portrayed as controlling all of creation, this does not require an understanding of these non-human characters as mere puppets of the Lord. As active agents, it is possible that they, like Jonah, may disobey the Lord. With regard to 4:10-11, Person says:

That nonhuman entities are considered active agents with value is confirmed in the final words of the narrative ... The Lord's rhetorical question certainly can be understood as a divine statement of the worth of the animals of Nineveh; the Lord has compassion for them as created beings. This statement also suggests that the Lord values the nonhuman characters as active agents in the divine plan for creation. ${ }^{71}$

Person argues that the final verse confirms the impression that the narrative does not draw a sharp distinction between humans and animals in terms of their contribution to advancing the plot and in establishing the satirical tone. ${ }^{72}$ In fact, he says, the most significant distinction between the characters concerns obedience to the Lord, with disobedient Jonah contrasted with all of the other human and non-human characters. In other words, the pagan humans are in the same category as the non-human characters. Person concludes that the target of the satirical tone therefore is not simply prophetic ethnocentrism, but also anthropocentrism in general. ${ }^{73}$

Yael Shemesh published an article titled “'And Many Beasts’ (Jonah 4:11): The Functions and Status of Animals in the Book of Jonah." "74 She also assumes that the book concludes with a rhetorical question, pointing out that scholars are almost unanimous in reading the final verse in this way. She states that she relates only to the world of the narrative itself, for which the ultimate fate of the Assyrian Empire is beyond the historical horizon. ${ }^{75}$ Her reading strategy leaves her with no other option than to interpret this verse as indicating "that

69 Conradie, "Ecological Hermeneutics,” 226.

70 Person, "Nonhuman Characters," 87.

71 Person, "Nonhuman Characters," 87.

72 Person, "Nonhuman Characters," 89.

73 Person, "Nonhuman Characters," 90.

74 See footnote 4.

75 Shemesh, "Function and Status of Animals," 3. 
divine mercy transcends human beings and includes animals as well." ${ }^{\text {76 }}$ Like Person, Shemesh emphasises the role of animals as agents of YHWH. ${ }^{77}$

With reference to Jonah 4:11, Shemesh also argues that animals have a similar status in the story of Jonah and in the flood narrative. ${ }^{78}$ Their fate, for better or for worse, depends on that of humans. In the story of the flood the animals are part of both the world that is destroyed and part of the remnant that is saved. After the flood the Lord makes a covenant with both human beings and all animals (Gen 9:9-11, 17). In the Jonah narrative the destruction of Nineveh would have entailed the death of the animals as well. The reprieve granted to the city also means the survival of the animals (Jonah 4:11), hence the connection between the Ninevites and their animals in 4:11.

Interestingly, Shemesh makes two conclusions that also reflect the two "masters" served by the literary elite in Persian Yehud, referred to by Handy: ${ }^{79}$ First, she summarises a section on animals as agents of YHWH, by saying that this portrayal of animals

serves the story's ideological line and sharpens its lesson: God's absolute control of His world, including the sea that terrifies human beings; and the criticism of Jonah, God's emissary, who, unlike the animals, attempts to evade his mission. ${ }^{80}$

Then she concludes the final section of her study, a section on the Lord's compassion for animals as follows:

[T]he last verses of the book show that we had it backwards: Jonah does not flee because God is a wrathful God, but because He is a merciful God ... Thus the book teaches us that the Lord's mercy is not reserved exclusively for "His people" but extends to all of His creation. ${ }^{81}$

In an article ${ }^{82}$ on biblical resources for preaching about creation, Kathryn Schifferdecker says that some environmentally minded Christians discount the use of the Bible as a resource for speaking of the natural world and the ecological crises we face in our time. Her study is an attempt to show that creation and its relationship to the Creator is a major concern of many of the biblical writers. To prove her point, she discusses, inter alia, the Jonah narrative. In her view, one of

76 Shemesh, "Function and Status of Animals," 3.

77 Shemesh, "Function and Status of Animals," 5-17.

78 Shemesh, "Function and Status of Animals," 16-17. See also E. W. Esse and I. M. Kikawa, "Jonah and Genesis 1-11,” AJBI 10 (1984): 3-5.

79 Handy, Jonah's World, 15.

80 Shemesh, "Function and Status of Animals," 17.

81 Shemesh, "Function and Status of Animals," 22.

82 See footnote 4. 
the remarkable things about the book is the role played in the narrative by nonhuman creatures. The text says that — as a king might appoint someone or something - God “appoints” or "allots” (מנה) not only the big fish, but several other non-human entities. ${ }^{83}$ The natural world is more obedient than the human prophet to God's call. God therefore uses animals, plants and storms to teach Jonah lessons about compassion, grace, and obedience.

Surprisingly, in The Green Bible the final verse of the book of Jonah is not printed in green, despite the way this verse has been read by the majority of scholars who attempted ecological interpretations of the narrative. ${ }^{84}$ The four passages in Jonah that have been printed in green may shed light on the matter $(1: 4 ; 1: 9 ; 2: 1-2$ [1:17-2:1]; $2: 10)$ : All four passages highlighted in this way in The Green Bible ${ }^{85}$ are about the power of God and the deity's ability to control nature. In 1:4 YHWH hurled a great wind upon the sea, and such a mighty storm came upon the sea that the ship threatened to break into pieces. Jonah 1:9 is about the creative power of $\mathrm{YHWH}$, the God of heaven, who made the sea and the dry land. In 2:1-2 [1:17-2:1] YHWH appointed a large fish to swallow up Jonah. From the belly of fish Jonah prayed to YHWH. And finally, in 2:10 YHWH instructed the fish to vomit Jonah out. Did the Green Bible team - consciously or unconsciously - align themselves with the discourse of empire, in which the ability to exercise power and perfect obedience are emphasised? According to the preface to The Green Bible the selection of passages to be printed in green was guided by four principles, two of which are how God and Jesus interacts with creation, and how nature responds to God. ${ }^{86}$ These two principles resonate well with the discourse of empire.

\section{CONCLUSIONS: SOME IMPLICATIONS FOR ECOLOGICAL INTERPRETATIONS OF BIBLICAL TEXTS}

This survey of readings of Jonah 4:10-11 has shown that the outcome of one's reading primarily depends on whether one reads the final verse as a rhetorical question, or as an assertion, or whether one opts for a double reading, which keeps both options in play. This study also considers the possibility that a double reading of this passage mirrors the double loyalty of the literary elite of Persian Yehud to Judean theology on the one hand, and Persian polity on the other. ${ }^{87}$

\footnotetext{
83 Schifferdecker, “Biblical Resources,” 216.

84 Cf. Green Bible, 906.

85 Cf. Green Bible, 905-906.

86 Green Bible, 1-16. The other two principles are that passages should show how all the elements of creation are interdependent, and how humans are called to care for creation.

87 Handy, Jonah's World, 15.
} 
Scholars who have attempted ecological interpretations of the narrative have unanimously opted for an interrogative reading of 4:11. A declarative reading would take the wind out of their sails. However, at the same time most of these scholars have exploited other passages in Jonah that seem to reflect imperial polity. The deity, for example, appoints "as a king might appoint someone or something;"88 the obedience of the appointed entities (fish, plant, worm, wind) is emphasised; and these entities serve as active agents of YHWH. ${ }^{89}$ A hermeneutics of suspicion and retrieval, however, has alerted Conradie to an instrumentalist use of motifs in the narrative, such as the fish, plant and worm. ${ }^{90}$

An interesting angle from which an ecological interpretation of the narrative could be done, concerns two phrases in 4:11, namely "Nineveh the great city" and "many animals," which represent two major revolutions in the history of humankind: the agricultural revolution during which a few species of animals and plants were domesticated, and the unification of humankind (empire-building). Studies have been done on how these revolutions have impacted on the environment. ${ }^{91}$ The title of this paper is phrased in terms of a question: Employing a distinction drawn by Habel, ${ }^{92}$ how "green," or alternatively "grey," are the concluding verses of the Jonah narrative? The answer seems to depend on how the final verse is read. However, the outcome of this study suggests that making use of these categories may prevent the reader from doing justice to the complexity and nuances which characterise the narrative. Reading the Jonah narrative again, elicited other, perhaps better questions: How do our multi-storied loyalties, as well as the major revolutions that have punctuated the story of humankind, impact on the way we speak about and relate to our environments?

\section{BIBLIOGRAPHY}

Ben Zvi, Ehud. Signs of Jonah: Reading and Rereading in Ancient Yehud. JSOTSup 367. Sheffield: Sheffield Academic Press, 2003.

. "Jonah 4:11 and the Metaprophetic Character of the Book of Jonah." JHebS 9 (2009). Article \#5. 13 pages. Online: http:www.jhsonline.org/Articles/article 107.pdf.

Bolin, Thomas M. “'Should I Not Also Pity Nineveh?’ Divine Freedom in the Book of Jonah.” JSOT 67 (1995): 109-120.

. Freedom Beyond Forgiveness: The Book of Jonah Re-examined. JSOTSupp 236. Sheffield: Sheffield Academic Press, 1997.

88 Schifferdecker, "Biblical Resources,” 216.

89 Person, "Nonhuman Characters," 87.

90 Conradie, "Ecological Hermeneutics," 226.

91 Noah Y. Harari, Sapiens: A Brief History of Humankind (London: Harvill Secker, 2014).

92 Norman C. Habel, An Inconvenient Text: Is a Green Reading of the Bible Possible? (Adelaide: ATF Press, 2009). 
476 Van Heerden, “Shades of Green - or Grey?,” OTE 30/2 (2017): 459-477

. "Eternal Delight and Deliciousness: The Book of Jonah after Ten Years."

JHebS 9 (2009). Article \#4. 11 pages. https://www.jhsonline.org? Article/article 106.pdf.

. "Jonah 4.11 and the Problem of Exegetical Anachronism." SJOT 24/1

(2010): 99-109. Doi: 10.1080/09018328.2010.491605.

Conradie, Ernst M. “An Ecological Hermeneutics.” Pages 219-227 in Fishing for

Jonah (Anew): Various Approaches to Biblical Interpretation. Edited by Louis Jonker and Douglas Lawrie. Stellenbosch: SUN Press, 2005.

Deist, Ferdinand E. Die God van Jona. Cape Town: Tafelberg, 1981.

Cooper, Alan M. "In Praise of Divine Caprice: The Significance of the Book of Jonah.” Pages 144-163 in Among the Prophets. Edited by Philip R. Davies and David J. A. Clines. Sheffield: Sheffield Academic Press, 1993.

Edelman, Diana V. "Jonah Among the Twelve in the MT: The Triumph of Torah over Prophecy." Pages 150-167 in The Production of Prophecy: Constructing Prophecy and Prophets in Yehud. Edited by Diana V. Edelman and Ehud Ben Zvi. London: Equinox, 2009.

Esse, E. W. and I. M. Kikawada. "Jonah and Genesis 1-11.” AJBI 10 (1984): 3-19.

Guillaume, Philippe. "The End of Jonah is the Beginning of Wisdom." Bib 87/2 (2006): 243-250.

Habel, Norman C. "Introducing Ecological Hermeneutics.” Pages 1-8 in Exploring Ecological Hermeneutics. Edited by Norman C. Habel and Peter Trudinger. Atlanta: Society of Biblical Literature, 2008.

. An Inconvenient Text: Is a Green Reading of the Bible Possible? Adelaide: ATF Press, 2009.

Halpern, Baruch and Friedman Richard E. "Composition and Paranomasia in the Book of Jonah.” HAR 4 (1980): 79-92.

Handy, Lowell K. Jonah's World: Social Science and the Reading of Prophetic Story. New York: Routledge, 2007.

Harari, Noah Y. Sapiens: A Brief History of Humankind. London: Harvill Secker, 2014.

Limburg, James. Jonah. OTL. London: SCM, 1993.

McKenzie, Steven L. “The Genre of Jonah.” Pages 159-171 in Seeing Signals, Reading Signs: The Art of Exegesis: Studies in Honour of Anthony F. Campbell, SJ for his Seventieth Birthday. Edited by Howard N. Wallace and Mark A. O’Brien. JSOTSup 415. Sheffield: Sheffield Academic Press, 2005.

Miles, John A. “Laughing at the Bible: Jonah as Parody.” JQR 65 (1974-1975): 168181.

Person, Raymond F. "The Role of Nonhuman Characters in Jonah.” Pages 85-90 in Exploring Ecological Hermeneutics. SBLSS 46. Edited by Norman C. Habel and Peter Trudinger. Atlanta: Society of Biblical Literature, 2008.

Sasson, Jack M. Jonah: A New Translation with Introduction, Commentary, and Interpretation. AB. New York: Doubleday, 1990.

Schifferdecker, Kathryn. “'And also Many Animals’: Biblical Resources for Preaching about Creation.” WW 27/2 (2007): 210-223.

Shemesh, Yael. “'And Many Beasts' (Jonah 4:11): The Function and Status of Animals in the Book of Jonah.” JHebS 10 (2010). Article \#6. 26 pages. http: //www.jhsonline.org/Articles/article_134.pdf. 
Van Heerden, “Shades of Green - or Grey?,” OTE 30/2 (2017): 459-477

Sherwood, Yvonne. A Biblical Text and its Afterlives: The Survival of Jonah in Western Culture. Cambridge: Cambridge University Press, 2000.

The Green Bible: A Priceless Message that Doesn't Cost the Earth. NRSV ed. London: Collins, 2008.

Trible, Phyllis. “Jonah.” Pages 461-529 in vol. 7 of The New Interpreter's Bible. Edited by Leander E. Keck. Nashville: Abingdon Press, 1996. . "A Tempest in a Text: Ecological Soundings in the Book of Jonah." Pages 187-200 in On the Way to Nineveh: Studies in Honor of George M. Landes. Edited by Stephen L. Cook and Sara C. Winter. Atlanta: Scholars Press, 1999. Verduin, M. De Spiegel van het Boek Jona. Kampen: J. H. Kok, 1984.

Wolff, Hans W. Obadiah and Jonah: A Commentary. Minneapolis: Fortress, 1986.

Prof Willie van Heerden, Department of Biblical and Ancient Studies, University of South Africa. Email: Vheersw@unisa.ac.za. 